\title{
The Tax Analysis of Special Purpose Fiscal Fund
}

\author{
Xiaoyan Shao \\ Aien International Institute, Dalian Jiaotong University, Dalian, 116021, China
}

\begin{abstract}
Keywords: Government subsidies; Fiscal funds for special use ; Accounting treatment
\end{abstract}
\begin{abstract}
In the process of the enterprises engaged in economic activities, they will receive government funding, and applied to the special purpose. Considering the way in which these payments for accounting and tax treatment, with how to fill in the relevant application form is required for the enterprise accounting personnel to master, at the same time, it is also a difficult problem encountered in the process of enterprise accounting personnel, tax cadres in daily work often encounter such problems. For this reason, this article in view of the special purpose of fiscal fund tax-related issues for specific elaboration, and to explore the relevant solutions.
\end{abstract}

\section{Introduction}

The main aim for government finances earmarks is to realize the industrial structure adjustment, promote our country economy level. Through the enterprise for special fiscal funds, the government realizes policy support. Considering the way in which this part of the enterprise to get money for the fiscal and taxation work processing is the key problem, this article mainly aims at the current stage of the accounting treatment and tax work were analyzed, and it hopes that through this article to fords the tax analysis of the special purpose of fiscal fund in China to help improve the capacity, to realize our country in the special payment accounting treatment and tax efficient ability to progress.

\section{The analysis of company obtained the special financial capital regulation}

Special fiscal funds mainly refers to the government that above the county level shall provide financial special projects, such as fiscal fund application in the building and technical transformation of fixed assets. This part of the money has specificity from the use of perspective, and it plays an important role for the enterprise grants related technology research and development. Special purpose financial appropriation part of government subsidies of accounting, to part, according to government regulations, complete the work related content.

Enterprise for special types of fiscal fund conditions include five types: first, direct investment by the government funds and funds; Second, it shall be undertaken by the government investment types of special funds content; Again, through various channels to obtain special funds; In addition, through the state's special transfer form to repay the money; Finally, in view of the enterprise special relocation compensation fees. The $16^{\text {th }}$ file of "ASBE" explicitly pointed out that government subsidies are for enterprises to obtain a free sex with monetary assets content or content subsidy is a monetary asset. The benefits do not include government investment in capital. Typically, government subsidies are often associated with assets or asset. Government subsidies assets part mainly refers to the enterprise can get related equipment purchase subsidies from the government, the asset part refers to the government for assets related subsidies. According to our country related content of the accounting standards issued by: nature of government subsidies for the monetary subsidies pertinent assets and earnings. In addition, this type of subsidies mainly adopts total income approach and method to measure way.

From the content point of view, this article is in view of the accounting control earmarks stipulated by the financial fund content. It has analyzed in the following aspects:

First, it is the nature of monetary assets part of government subsidies. In general, the enterprise can obtain the monetary subsidies, the government through the bank transfer form to the enterprise to provide special allowance, and according to the actual measured reap the benefits. It is important to 
note with clear evidence is required, within each certification government allocated special funds for a fixed norm and the appropriation of the implementation, such as special funds used to be combined with the actual sales situation and quota calculation provide subsidies.

Second, the government provides the proportion of the assets non-monetary benefits.

The nature is not of the assets that government subsidies must be completed in combination with the fair value measurement. This is because the fair value itself has the characteristics of reliability, it must be completed through actual nominal value. Special purpose of fiscal fund subsidy for non-monetary assets part, such as asset pricing is attached file with the protocol such as required. Therefore, the nature of non-monetary assets subsidies must present relevant documents, to indicate that the fair value to exist. Against to the fair value or fair value difference big, fair value should be combined with the market price as a reference to complete the measurement.

Thirdly, it is based on analysis of assets, the relevant part of the government subsidies. It refers to enterprises for application in building long-term assets on subsidies or other ways. This paper puts forward the related to assets refers to the link of construction of fixed assets and intangible assets part of long-term assets. Enterprise assets related to financial aid does not reflect the profits and losses of the current results. Therefore, we should confirm the project debt, according to the relevant content of form and available time, average on the service life of the asset allocation, using time into the profits and losses of the way to realize the non-operating income measurement. In addition, note there are some part will happen before the end of the service life of the asset transferred or other forms of damage, for this part have not allocated to part by way of deferred earnings.

Fourthly, it is based on analysis of income related government subsidies. This part mainly pointer the content of the fiscal subsidy for assets associated. This type of government subsidies are not needed by building or other forms for long-term assets, and as a condition of policy or related conditions of use. This part of the subsidy is mainly used in the late for business expenses and losses, the related cost measurement in non-operating income section; it is applied to compensate for the expenses and losses of enterprises.

For a special purpose companies capital accounting work related to study assumes that the instance. The special purpose financial fund related enterprise accounting work on several aspects: first, enterprise assets management and application of related special USES capital mainly refers to the enterprises purchase that related production equipment in the production activity class financial capital. This part cannot be directly as the profits and losses of the current, capital operation and application form to apply deferred revenue. In the enterprise accounting work, in other words, once the money after reaching confirmed using standard can realize the capital operation of the distribution of average life expectancy, according to certain standard after evenly assigned to each stage in the profit and loss. Second, the enterprise income related financial fund for handling to separately from the other accounting work, with the enterprise realize independent management. Enterprises for special use app in the compensation of the late fee is calculated, it is using deferred income or losses when needed, and it should be confirmed in the process and relevant expenses included in the current profits and losses.

Case study: some enterprises in the special usage of fiscal fund 2.4 million yuan, the main purpose to improve the production process, the purchase of new technology and equipment. The enterprise through the use of the funds to purchase equipment cost 2.4 million yuan, and expected service life of the equipment for 10 years with no residual value.

The enterprise gets funds: borrow, bank deposits, 240; Credit: deferred income, 240; The company by buying equipment implementation:

Borrow, fixed asset 240; Credit, bank deposits, 240; Monthly depreciation of enterprise: borrow, manufacturing cost 2; Credit, accumulated depreciation 2; Borrow, deferred income 2, Credit, non-operating revenue. 2.

In the process of special fiscal funds in the enterprise accounting, the enterprise all accounted for as non-operating income calculated total $240000 \mathrm{RMB}$. 


\section{Based on the tax related problem analysis the special fiscal fund project}

Fiscal capital from tax perspective should consider two aspects: first of all, it is the special fiscal revenue usability; Second, the special fiscal fund from the content of the project belongs to the tax-free income. Special government fiscal appropriations of tax problem involves very wide range of content of tax policy. Therefore, to the state Treasury and the IRS is combined with the actual situation made the special provisions, such as one of the most main three rules.

First, the problem of tax funding from the government fiscal special involved in enterprise production and business operation activities of related fund and national financial department transfer the money. In addition, special funds mainly refers to the countries do not involve in the tax portion of the capital projects. Since 2008 our country ministry of finance and the related tax department puts forward the specific provision, the mainly use of fiscal funds and fords the tax situation. Relevant governmental fund 151 file points out that enterprises obtain the financial part of the transfer and the relevant government subsidies and discount loans and other special funds content can direct reduction part of value added tax, or it can be used to tax return back, etc. Above the content does not include a case involved, namely enterprise of export tax refunds. In the file clear several specific situation, it points out the fiscal fund first, enterprise can measurement and income does not include the investment of enterprise internal financial capital in the country, and also except state investment funds after use of the principal forms. Secondly, in view of the enterprise development for the national special purpose financial capital will is beyond the scope of tax. At the same time, the national tax authorities issued by special purpose fund is no longer measuring tax amount. Third, part of the business unit or department related groups on some of the budget management and development funds mainly rely on the finance department for transfer, this part of the budget management is mainly supported by the higher subsidies, not as a tax revenues.

Second, by the state administration of taxation and ministry of finance jointly issued special provisions includes eligible enterprises cannot be tax income, when to calculate the total amount of tax for making this part of content. When enterprise accounting work calculating the total taxable business spending costs, the enterprise income tax in the partial do not deduct tax content. According to the related contents in the course of forming assets enterprises; the corresponding tax amount determined to remove a part or the related content of the computation of depreciation amortization. In addition, the tax treatment of enterprise fiscal fund, some will meet the requirements as prescribed in the tax money for not processing. This part meets the conditions of financial capital, the enterprise future development spending five years did not happen and there is not to pay back the money for new revenue and calculation. If this part of funds to recalculate the spending behavior occurs, it should be related to deduct tax income.

Through the above two tax rules content can be found that the fiscal and taxation, No. 87 document relative to the content is more operable in both tax and company for characteristics and feasibility.

Third, by comparing the above two files, it can be found both in terms of content broadly, there are subtle differences lies in the using time of No. 87 document mainly during 2008 to 2010, No. 70 is for after January 1, 2011.

Fourth, to sum up, this paper discusses the related special use fiscal capital in confirmation of some details, work enterprise accounting and tax treatment mainly exist in time difference characteristics. Therefore, in the process of tax processing, it is to obtain the special fiscal fund, after the receipt of all the current response to this money included in taxable income. It will not produce deferred confirmed later. In addition, it still need to the current accounting that not able to identify non-operating income complete tax increase, and then the year is measured by way of decreasing year by year.

\section{The tax return analysis of special purpose for fiscal fund}

Special instance analysis with fiscal fund, in 2014, A business enterprise income tax return related process conditions were analyzed, and the forming process of the following content: 
First of all, on the schedule of income non-business income options to fill in the part, content of the project including the taxpayers expect total compensation funds. This case study amount to fill selected 24; second, paying taxes is adjusted to fill in the list of parts, the main content of the project to adjust income fill selected should be combined with deferred payments. Declaration should pay attention to other projects related to the taxpayer; it can obtain the government subsidies don't belong to tax part of the total content.

Second, the amount of case study to fill 2, 4, tax amount selected 240, increase amount selected 216. Now in this instance properties for special use fiscal fund levy income, which do not include the tax adjustment project schedule of line 14 project income adjustment type project of the tax-free income (including the way value of 240). In addition, 38 line project to deduct such adjustment of tax-free incomes formed by the application in spending cost (including amount shown in account books 24, increase amount24). Note equipment purchase scrap in advance or take relevant measures dealing with cases, after2013 the nine years, viscosity businesses can get tax year tax return need to fill in with other process: first, fill in the schedule of income among 24 lines non-operating income (include government subsidies income) 24. Second, the first of the tax adjustment project schedule is a line item types of income adjustment projects (including confirmed deferred revenue government subsidies). Third, in view of the tax adjustment project detailed deduction of class projects include tax-free incomes and application in formed by expenses (including amount shown in account books need to fill in 24, increase amount should fill in 24).

\section{Conclusion}

To sum up, the main aim of the government fiscal special funds allocated is to improve enterprise's investment in the business environment, realize the stable and effective development of enterprise and the local economy. Therefore, enterprise should be aimed at the current economic policy environment, effective use of relevant supporting government policy. By studying the content of the government fiscal and tax policies, a sound system of special management, improve management accounting work process, effective handling tax issues; really to promote the ability of enterprise in the market competition environment.

\section{Acknowledgments}

This paper 2014 subject in LiaoNing province education science "twelfth five-year" plan, named" the fiscal policy to promote the development of higher education undertaking research", number: JG14DB078.

\section{References}

[1] Lv Shuming. Special purpose of fiscal capital income tax differences between accounting and tax treatment analysis. China's securities and futures, 2013,06:128.

[2] Wang Guilian. The notice of enterprise income tax treatment about the special purpose of fiscal capital. Liugang technology,2012,03:62.

[3] Ni Xinfeng, Miao Hongli, Zhao Lumeng. Enterprise obtained the special fiscal fund under the new rules of accounting and tax treatment. Journal of economist, 2013, 10, 116-117.

[4] The ministry of finance, the state administration of taxation. Deal with the problem of enterprise income tax on special fiscal fund notice. finance and taxation [2011] No. 70. China accounting of trade unions, 2011, 11:61.

[5] The ministry of finance, state administration of taxation on special fiscal fund notice on the problem of enterprise income tax treatment. China union accounting, 2012,08:63. 
[6] The ministry of finance, state administration of taxation on special fiscal fund notice on the problem of enterprise income tax treatment. Chinese tax, 2014,09:33.

[7] Liao Jie, Ge Cunzhuang, Fei Bin, About the special purpose of fiscal fund notice on the problem of enterprise income tax treatment. Journal of accounting, 2012,09:112 